\title{
Biophysical controls of evapotranspiration in cowpea cultivation under different water regimes
}

\author{
Daniely F. S. de Souza ${ }^{1}$, João V. de N. Pinto², Deborah L. P. Costa ${ }^{2}$, Igor C. de O. Vieira², \\ Thieres G. F. da Silva ${ }^{3}$ \& Paulo J. de O. P. de Souza ${ }^{1}$
}

${ }^{1}$ Universidade Federal Rural da Amazônia/Instituto Socioambiental e dos Recursos Hídricos. Belém, PA, Brasil. E-mail: florenciadany@hotmail.com
(Corresponding author) - ORCID: 0000-0001-9484-9459; paulo.souza@ufra.edu.br - ORCID: 0000-0003-4748-1502
${ }^{2}$ Universidade Federal Rural da Amazônia. Belém, PA, Brasil. E-mail: jvitorpinto@gmail.com - ORCID: 0000-0001-5194-0834; deborahpires@gmail.com -
ORCID: 0000-0002-3513-0759; cristianigor67@gmail.com - ORCID: 0000-0002-0488-5008
${ }^{3}$ Universidade Federal Rural de Pernambuco/Unidade Acadêmica de Serra Talhada. Serra Talhada, PE, Brasil. E-mail: thieres.silva@ufpe.br - ORCID: 0000-
0002-8355-4935

\begin{abstract}
The objective of this study was to analyze the variations of the decoupling factor and the aerodynamic and stomatal conductances for cowpea subjected to different levels of water availability during the reproductive phenological stages of the crop. The study was conducted in the municipality of Castanhal located in the northeast of the state of Pará, Brazil, in an area planted with cowpea, in 2013, 2014 and 2015 with four irrigation treatments: T100 - replacement of 100\% of the crop evapotranspiration (ETc); T50 replacement of $50 \%$ ETc; T25 - replacement of $25 \%$ ETc; and T0 - without any replacement (without irrigation). The interaction between the crop and the atmosphere in water vapor exchange was estimated through the decoupling factor $(\Omega)$, which was between 0.5 and 1 , except for the treatment without irrigation, indicating a moderate to high decoupling between the crop and the atmosphere, so that the water vapor exchange process was controlled by the energy supply, instead of stomatal control.
\end{abstract}

Key words: Vigna unguiculata (L.) Walp, decoupling factor, aerodynamic conductance, stomatal conductance

\section{Controles biofísicos da evapotranspiração em cultivo de feijão-caupi sob diferentes regimes hídricos}

RESUMO: Objetivou-se com esse trabalho analisar as variações do fator desacoplamento, das condutâncias aerodinâmica e estomática para o feijão-caupi submetido a diferentes níveis de disponibilidade hídrica durante os estádios fenológicos reprodutivos da cultura. O estudo foi conduzido no município de Castanhal, situado no nordeste do estado do Pará, em uma área cultivada nos anos de 2013, 2014 e 2015 com quatro tratamentos de irrigação: T100 - reposição de 100\% da evapotranspiração da cultura (ETc); T50 - reposição de 50\% ETc; T25 - reposição de $25 \%$ ETc; e T0 - sem reposição (sem irrigação). A interação entre a cultura e a atmosfera na troca de vapor d'água foi estimada por meio do fator de desacoplamento $(\Omega)$, o qual esteve entre 0,5 e 1 , exceto para o tratamento sem irrigação, indicando um desacoplamento de moderado alto entre a cultura e a atmosfera, de modo que o processo de troca de vapor d'água foi controlado pelo suprimento de energia, ao invés do controle estomático.

Palavras-chave: Vigna unguiculata (L.) Walp, fator de desacoplamento, condutância aerodinâmica, condutância estomática 


\section{INTRODUCTION}

Although cowpea [Vigna unguiculata (L.) Walp.] is relatively tolerant to water deficit, there may be yield losses of up to $76 \%$ when it occurs during the reproductive stage of the crop (Lima et al., 2011). In order to make adequate irrigation management and mitigate these losses, it is fundamentally important to determine the water requirement of the crop, which can be obtained by quantifying the water losses through evapotranspiration.

Atmospheric demand and characteristics of the vegetated surface aerodynamically and physiologically regulate evapotranspiration through canopy roughness and stomatal activity (Silva et al., 2012; Fraga et al., 2015). Aerodynamic conductance is related to the turbulent atmospheric processes and is the parameter that represents the conductivity of this turbulent activity in the air layer close to the surface. Stomatal conductance is the physiological variable that controls the water vapor flux from the leaf to the atmosphere through the stomatal pore and is the mechanism which best represents the control of evapotranspiration in plants (Paulino Junior et al., 2017).

Based on the association of these aerodynamic and stomatal conductances of Penman-Monteith equation (Allen et al., 1998), McNaughton \& Jarvis (1983) developed the concept of decoupling factor $(\Omega)$, an indicator of the interaction between the surface and the atmosphere, which allows establishing whether evapotranspiration is mainly controlled by either the vapor pressure deficit and stomatal conductance or the radiation balance (Silva et al., 2012; Fraga et al., 2015).

Therefore, the objective was to analyze the variations of the decoupling factor and aerodynamic and stomatal conductances for cowpea subjected to different levels of water availability and during the reproductive phenological stages of the crop in the northeastern region of Pará state, Brazil.

\section{Material and Methods}

The study was conducted at the Escola Fazenda de Castanhal (EFC), belonging to the Universidade Federal Rural da Amazônia, located in the municipality of Castanhal, northeastern region of Pará state, Brazil ( $1^{\circ} 19^{\prime} 24.48^{\prime \prime}$ S; $47^{\circ}$ $57^{\prime} 38.20^{\prime \prime} \mathrm{W}, 47 \mathrm{~m}$ ). The climate of the region is Am (monsoon tropical), according to Köppen's climatic classification (Alvares et al., 2013), with a moderate dry season and average annual precipitation of $2,500 \mathrm{~mm}$. The driest period of the year occurs from June to November, whereas the period of highest precipitation is observed from December to May. The average annual temperature is $27^{\circ} \mathrm{C}$, with maximum and minimum of 35 and $18^{\circ} \mathrm{C}$, respectively. The average air relative humidity is $82.5 \%$, with average annual insolation of $2,300 \mathrm{~h}$ and average wind speed of $1.75 \mathrm{~m} \mathrm{~s}^{-1}$ (INMET, 2009).

The soil of the study area was classified as an Oxisol, with the following textural composition: $72 \%$ of sand, $12 \%$ of silt and $16 \%$ of clay, which characterizes a sandy texture.

The experiment was carried out from October to December 2013 and from September to November in 2014 and 2015, in an area of 1.5 ha. The cultivar used was BR3-Tracuateua, which has an indeterminate, prostrate growth habit, cycle of 60-70 days, and is more recommended for the edaphoclimatic conditions of northeastern region of Pará state (Freire Filho et al., 2009). Soil moisture contents at field capacity and permanent wilting point were 0.250 and $0.065 \mathrm{~m}^{3} \mathrm{~m}^{-3}$, respectively.

The area was conventionally tilled and sowing was performed manually in the experimental area. The crop received all cultivation practices needed to allow the genotype to express its maximum production potential. Liming and fertilization were performed according to the results of the soil chemical analyses, following the fertilization recommendations of EMBRAPA (2006).

The experimental design was randomized blocks, with four treatments and six blocks (repetitions). The experimental units consisted of $2 \times 0.5 \mathrm{~m}$ areas, each containing 10 plants, separated by $2 \mathrm{~m}$ border from adjacent treatments.

From the reproductive stage of the crop, four treatments began to be applied (T100, T50, T25 and T0), because this is the most sensitive phase to water deficit. The crop was subjected to different water restrictions, which consisted in the replacement of different percentages of the water volumes lost by evapotranspiration: T100 - replacement of $100 \%$ of the crop evapotranspiration (ETc); T50 - replacement of 50\% ETc; T25 - replacement of 25\% ETc; and T0 - without any replacement (without irrigation).

The phenological scale proposed by Fernández et al. (1986), adjusted for cowpea by Farias et al. (2017), was used in this experiment considering the following stages: R5 (first floral bud), R7 (first exposed pod), R8 (grain filling) and R9 (physiological maturity). Cowpea phenology was monitored daily from sowing to harvest in every year.

During the vegetative stage, cowpea cultivation was uniformly irrigated on a daily basis using a drip system, with an average flow rate of $0.605 \mathrm{~L} \mathrm{~h}^{-1}$ per dripper, for a pressure of 5 m.w.c., in order to replace the water lost by evapotranspiration.

As the study was conducted in the field, plants also received water from occasional rains that occurred during the experiments. When rain events exceeding ETc occurred, irrigation was suspended in order not to raise soil moisture $(\theta s)$ to a level above field capacity.

Crop evapotranspiration (ETc) was established by the product between the reference evapotranspiration (ETo) and crop coefficient (Kc), according to Bastos et al. (2008) for each phenological stage. ETo was estimated on a daily basis by the Penman Monteith-FAO method (Allen et al., 1998), with data obtained from an automatic station of the Instituto Nacional de Metereologia - INMET located $3 \mathrm{~km}$ away from the area.

ETc was considered as the net irrigation depth (NID). However, the gross irrigation depth (GID) to be applied was obtained by the relationship between NID and the water application efficiency (Ea) of the system, considered as $85 \%$.

The sequential water balance was performed according to Carvalho et al. (2011) in order to quantify the deficits imposed by the treatments subjected to water deficit. The effective depth of the root system and the available water capacity (AWC) used were 250 and $53 \mathrm{~mm}$, respectively (Souza et al., 2017).

Meteorological data were measured by sensors installed on a 3.0-m-high micrometeorological tower located in the 
experimental area. The tower had border greater than the 1:100 ratio, in the predominant direction of the winds (northeast), in order to prevent advective effects from interfering in the measurements taken in the crop (Souza et al., 2011).

The following meteorological variables were monitored: air temperature and air relative humidity (HMP155A, Vaisala, Helsinki, Finland), incident global solar radiation (CMP3, Kipp \& Zonen, Delft, Netherlands), atmospheric pressure (278, Setra, Boxborough, USA), wind speed (Marine 05106, Young, Traverse City, USA), precipitation (TB4, Campbell Scientific, Logan, USA) and soil moisture (CS615, Campbell Scientific, Logan, USA). The sensors were connected to a data acquisition system (CR1000, Campbell Scientific, Logan, USA) and a multiplexer (AM416, Campbell Scientific, Logan, USA), with readings taken every 10 seconds and averages and totals recorded every $10 \mathrm{~min}$. This study considered the hourly averages in the interval between 8 and $16 \mathrm{~h}$ on the days of stomatal conductance measurement.

The decoupling factor $(\Omega)$ of the crop relative to the atmosphere, proposed by McNaughton \& Jarvis (1983), was determined using the method described by Silva et al. (2012) in order to evaluate the sensitivity of cowpea evapotranspiration to the control exercised by the meteorological conditions and by the plant itself for the region of study (Eq. 1). When $\Omega$ is equal to or close to 0 (zero), the control is exerted by stomatal conductance, that is, the biotic factor prevails over evapotranspiration. By contrast, when $\Omega$ is close to 1 (one), the external conditions are determinant in the process, especially the radiation balance.

$$
\Omega=\frac{\Delta+\gamma}{\Delta+\gamma\left(1+\frac{\mathrm{g}_{\mathrm{a}}}{\mathrm{g}_{\mathrm{s}}}\right)}
$$

where:

$\Omega$ - decoupling factor (dimensionless)

$\Delta=\left(4098 \mathrm{e}_{\mathrm{s}}\right) /(\mathrm{T}+237.3)^{2}$ - slope of the saturation vapor pressure curve vs. temperature $\left(\mathrm{kPa}^{\circ} \mathrm{C}^{-1}\right)$;

$\gamma=\left(\mathrm{C}_{\mathrm{p}} \mathrm{P} / 0.622 \lambda\right) \gamma-$ psychrometric coefficient, $\mathrm{kPa}^{\circ} \mathrm{C}^{-1}$;

$\mathrm{g}_{\mathrm{a}} \quad$ - aerodynamic conductance, $\mathrm{m} \mathrm{s}^{-1}$;

$\mathrm{g}_{\mathrm{s}} \quad$ - stomatal conductance, $\mathrm{m} \mathrm{s}^{-1}$;

$\mathrm{e}_{\mathrm{s}} \quad$ - saturation vapor pressure, $\mathrm{kPa}$;

$\mathrm{T} \quad$ - air temperature, ${ }^{\circ} \mathrm{C}$;

$\mathrm{C}_{\mathrm{p}}$ - specific heat of air at constant pressure, $1.013 \times 10^{-13}$ $\mathrm{MJ} \mathrm{kg}{ }^{-1}{ }^{\circ} \mathrm{C}^{-1}$;

$\mathrm{P}$ - atmospheric pressure, $\mathrm{kPa}$; and,

$\lambda \quad$ - latent heat of vaporization of water, $2.45 \mathrm{MJ} \mathrm{kg}^{-1}$.

The stomatal conductance to vapor diffusion $\left(g_{s}\right)$ was measured using a portable infrared gas analyzer (IRGA LI6400, Li-Cor, Nebraska, USA). For the collection protocol, the photosynthetic photon flux density (PPFD) was fixed at $1,500 \mu \mathrm{mol} \mathrm{m} \mathrm{m}^{-2} \mathrm{~s}^{-1}$ and $\mathrm{CO}_{2}$ concentration was fixed at $400 \mu \mathrm{mol} \mathrm{mol}^{-1}$; the temperature and relative humidity of the air followed the environmental conditions.

The measurements were taken from the beginning of the treatments, on pre-defined days corresponding to the phenological stages R5, R7, R8 and R9 (Table 1), between 8 and
Table 1. Days after sowing defined for the collection of stomatal conductance data

\begin{tabular}{cccc|}
\hline $\begin{array}{c}\text { Phenological } \\
\text { stage }\end{array}$ & \multicolumn{3}{c|}{ Days after sowing (DAS) } \\
\cline { 2 - 4 } R5 & $\mathbf{2 0 1 3}$ & $\mathbf{2 0 1 4}$ & $\mathbf{2 0 1 5}$ \\
R7 & - & 37 & 34 \\
R8 & 41 & 43 & 39 \\
R9 & 47 & 50 & 46 \\
\hline
\end{tabular}

R5 - First floral bud; R7 - First exposed pod; R8 - Grain filling; R9 - Physiological maturity

$16 \mathrm{~h}$, with 1-h intervals between measurements. Two plants were selected in each treatment, in the six blocks. The samples were collected in the central leaflet of the third or fourth leaf, counted from the apex; the leaves were in good phytosanitary condition and fully expanded.

Aerodynamic conductance $\left(\mathrm{g}_{\mathrm{a}}\right)$ was obtained by the inversion of Eqs. 2 (Allen et al., 1998) and 3.

$$
r_{a}=\frac{\ln \left[\frac{Z_{m}-d}{Z_{0 m}}\right] \ln \left[\frac{Z_{h}-d}{Z_{0 h}}\right]}{k^{2} U_{z}}
$$

where:

$\mathrm{r}_{\mathrm{a}} \quad$ - aerodynamic resistance, $\mathrm{m} \mathrm{s}^{-1}$;

$\mathrm{Z}_{\mathrm{m}} \quad$ - wind speed measurement height, $\mathrm{m}$;

$\mathrm{d}$ - zero-plane displacement of wind profile, $\mathrm{m}$;

$\mathrm{Z}_{0 \mathrm{~m}}$ - roughness parameter for momentum, m;

k - Von Kárman constant, 0.41;

$\mathrm{U}_{\mathrm{z}} \quad$ - wind speed at height $\mathrm{Z}, \mathrm{m} \mathrm{s}^{-1}$;

$\mathrm{Z}_{\mathrm{h}} \quad$ - air humidity measurement height, $\mathrm{m}$; and,

$Z_{0 h}$ - roughness parameter for sensible heat and water $\operatorname{vapor}(\mathrm{m})$.

$$
\mathrm{g}_{\mathrm{a}}=\frac{1}{\mathrm{r}_{\mathrm{a}}}
$$

where:

$\mathrm{g}_{\mathrm{a}} \quad$ - aerodynamic conductance, $\mathrm{s} \mathrm{m}^{-1}$.

The zero-plane displacement (d) and roughness parameter for momentum $\left(\mathrm{Z}_{0 \mathrm{~m}}\right)$ were estimated through the average plant height (h) according to Eqs. 4 and 5 (Brutsaert, 1982).

$$
\begin{aligned}
\mathrm{d} & =\frac{2}{3} \mathrm{~h} \\
\mathrm{Z}_{\mathrm{om}} & =0.123 \mathrm{~h}
\end{aligned}
$$

In turn, the roughness parameter governing the transfer of sensitive heat and water vapor $\left(\mathrm{Z}_{0 \mathrm{~h}}\right)$ was obtained from the estimates of $Z_{0 \mathrm{~m}}$, considering the following relationship (Allen et al., 1998):

$$
\mathrm{Z}_{\mathrm{oh}}=0.1 \mathrm{Z}_{\mathrm{om}}
$$

The average plant height was determined by the average height of plants randomly chosen (2 per block and 12 per treatment) on the same days in which $g_{s}$ data were collected. 
The height was measured from the soil to the leaf located at the highest point of the plant. According to field observations, there was no difference in plant height between treatments, probably because they were irrigated equally in the initial (vegetative) phase, in order to meet the requirements for germination and establishment of the crop.

The data of the climatic variables were analyzed based on means and standard deviation, whereas the data of $\theta \mathrm{s}, \mathrm{g}_{\mathrm{s}}$ and $\Omega$ were subjected to analysis of variance and Tukey test at $\mathrm{p} \leq 0.05$.

\section{Results AND Discussion}

The total precipitation values observed during the experiments of 2013, 2014 and 2015 were 207.51, 158.49 and $30.73 \mathrm{~mm}$, respectively. The scenario of soil water conditions is shown in Figure 1. The few rains in 2015 are related to the occurrence of the atmospheric-oceanic phenomenon El Niño in the region (Grimm, 2015), which inhibits the formation of clouds and, consequently, the occurrence of rains in eastern Amazon (Coelho et al., 2012).

Despite the difference in the precipitation volume between the experimental years, especially in 2015, the replacement of the evapotranspired water volume through irrigation kept the soil moisture between field capacity (FC) and permanent wilting point (PWP) for all treatments during the vegetative stage (Figure 1).

For the daytime period of the days selected for the study, the average air temperature (Tair) was $30.8 \pm 0.2{ }^{\circ} \mathrm{C}(2013)$, $30.5 \pm 1.0^{\circ} \mathrm{C}(2014)$ and $33.0 \pm 0.4{ }^{\circ} \mathrm{C}(2015)$; and the average air relative humidity $(\mathrm{RH})$ was $70.8 \pm 2.1 \%$ (2013), $68.9 \pm 8.5 \%$ (2014) and $53.7 \pm 6.7 \%$ (2015) (Figure 2). The average daytime values of global solar radiation $(\mathrm{Rg})$ were $385.60 \pm 47.43(2013)$, $310.15 \pm 18.59$ (2014) and $524.23 \pm 134.63 \mathrm{~W} \mathrm{~m}^{-2}$ (2015). The highest variation range of Tair observed in the daytime period in 2015 (Figure 2) was related to the occurrence of the El Niño phenomenon. Thus, the elevated values of Tair and $\mathrm{Rg}$ are due to low cloudiness (Campos \& Alcantara, 2016).

The average wind speed $\left(\mathrm{U}_{2}\right)$ was equal to $1.19 \pm 0.36$ (2013), $1.20 \pm 0.63$ (2014) and $1.41 \pm 0.48 \mathrm{~m} \mathrm{~s}^{-1}$ (2015). At 58 DAS (2015), there was a reduction in wind speed compared to the other days, possibly because of the reduction of solar radiation on this day. The average water vapor pressure deficit (VPD) was $1.31 \pm 0.08 \mathrm{kPa}$ (2013), $1.62 \pm 0.52 \mathrm{kPa}$ (2014) and $2.89 \pm 0.31 \mathrm{kPa}(2015)$. The high values of VPD in the year 2015 demonstrated the high atmospheric demand for water vapor. The high capacity of the atmosphere to absorb water vapor, because of the dry air, can be explained by the reduced precipitation observed during this period.

The values of stomatal and aerodynamic conductance are presented in Figure 3. The diurnal variability of stomatal conductance was similar to the pattern of alteration of the meteorological variables, especially solar radiation, air temperature and vapor pressure deficit, evidencing a relationship between them (Oliveira et al., 2005). Lima et al. (2016), in a study with cowpea under conditions of full water supply in the soil, show that stomatal conductance is modulated mainly by these three variables.

This behavior is also influenced by soil moisture (Oliveira et al., 2005). This interference is clearly evidenced from the response between the different treatments (Figure 3).

On an hourly scale for T100, T50 and T25, it can be noted that the increase in $\mathrm{g}_{\mathrm{s}}$, at the beginning of the daytime period, was associated with the availability of energy, which favored
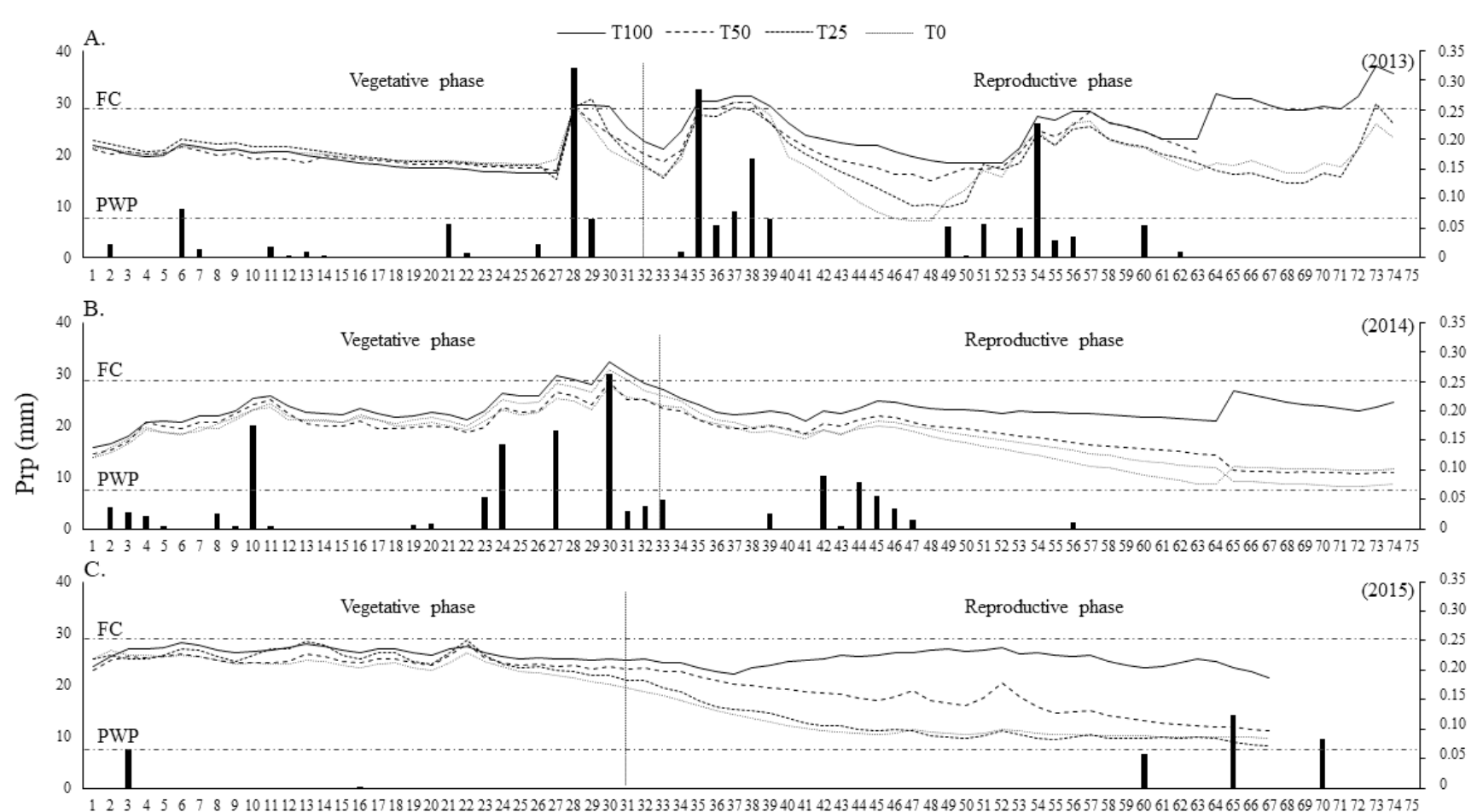

DAS

T100 - Replacement of 100\% of the crop evapotranspiration (ETc); T50 - Replacement of 50\% ETc; T25 - Replacement of $25 \%$ ETc; and T0 - without eplacement (without irrigation); FC - Field capacity; PWP - Permanent wilting point; The reproductive period began at 32, 33 and 31 days after sowing (DAS), respectively for the years 2013 , 2014 and 2015

Figure 1. Precipitation (Prp) and soil moisture ( $\theta$ s) throughout the cowpea (Vigna unguiculata L. Walp) cycle in the years 2013 (A), 2014 (B) and 2015 (C), under the climatic conditions of the municipality of Castanhal, PA state, Brazil 

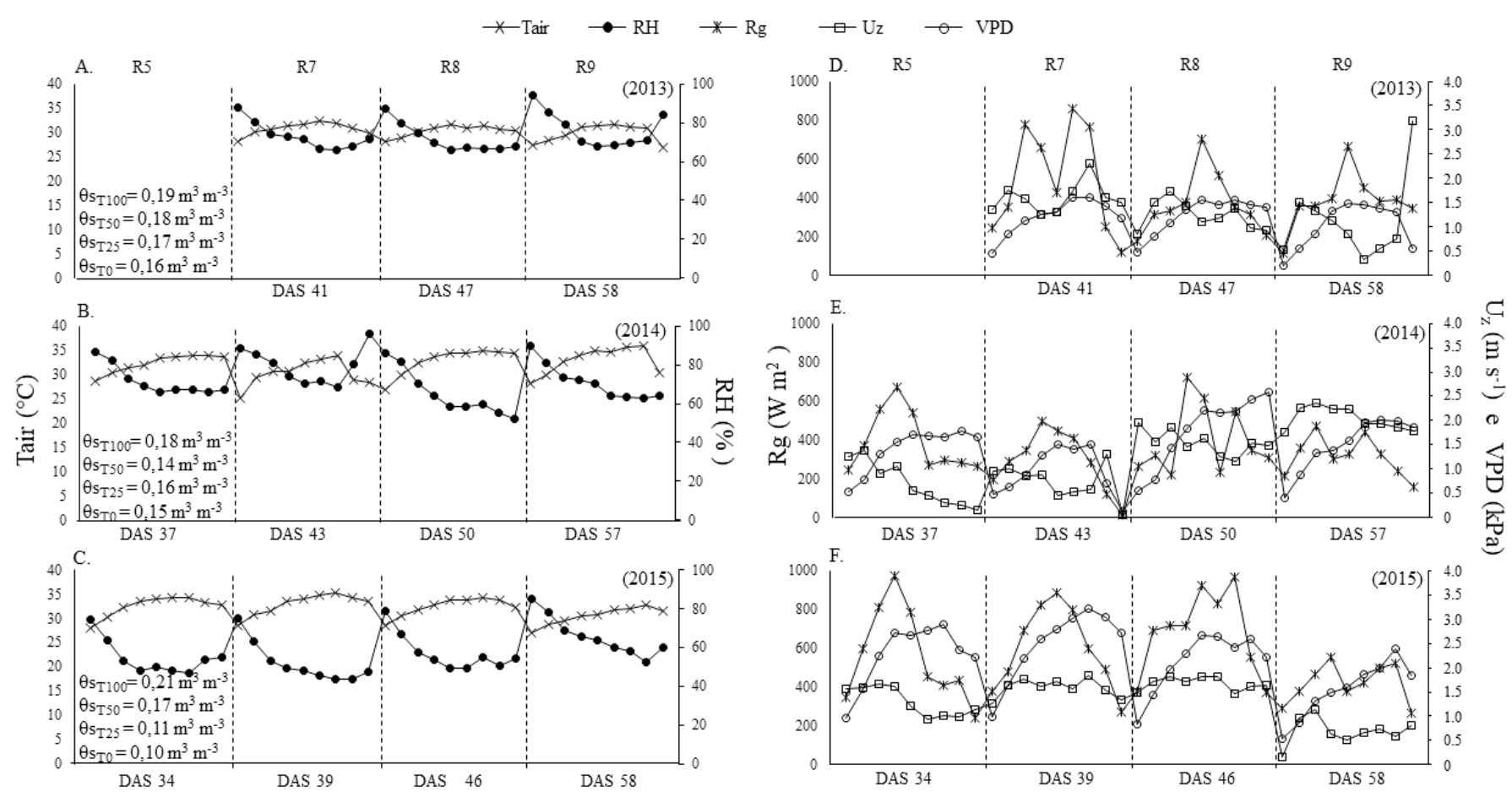

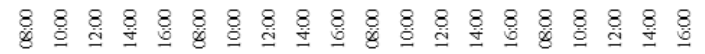

Local time

RH - Air relative humidity; Tair - Air temperature; Rg - Global solar radiation; U - Wind speed; VPD - Vapor pressure deficit; R5 - First floral bud); R7 - First exposed pod; R8 - Grain filling; R9 - Physiological maturity; $\theta \mathrm{s}_{\mathrm{T} 100} \theta \mathrm{s}_{\mathrm{T} 50,}, \theta \mathrm{s}_{\mathrm{T} 25} \theta \mathrm{s}_{\mathrm{T} 0}$ - Soil moisture content, respectively, in the treatments T100 - Replacement of $100 \%$ of the crop evapotranspiration (ETc); T50 - Replacement of 50\% ETc; T25 - Replacement of $25 \%$ ETc; and T0 - without replacement (without irrigation); DAS - Days after sowing

Figure 2. Mean hourly variation of climatic variables during the daytime period in four phenological stages representative of the reproductive phase of irrigated cowpea (cv. BR3-Tracuateua), in the years 2013 (A and D), 2014 (B and E) and 2015 (C and F), under the climatic conditions of northeastern region of Pará state, Brazil

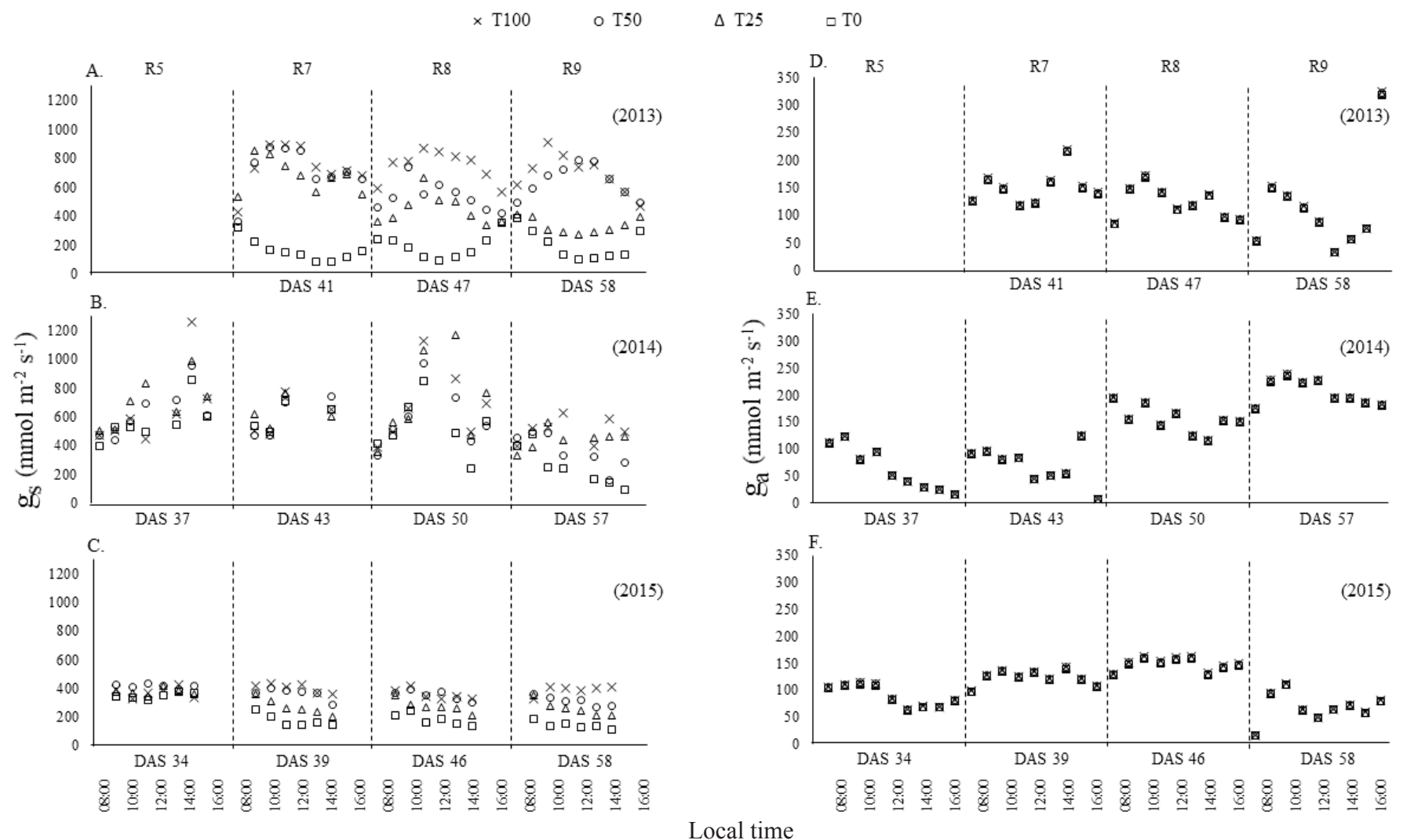

T100 - Replacement of $100 \%$ of the crop evapotranspiration (ETc); T50 - Replacement of 50\% ETc; T25 - Replacement of $25 \%$ ETc; and T0 - without replacement (without irrigation); R5 - First floral bud; R7 - First exposed pod; R8 - Grain filling); R9 - Physiological maturity; DAS - Days after sowing

Figure 3. Mean hourly variation of stomatal conductance $\left(\mathrm{g}_{\mathrm{s}}\right)$ and aerodynamic conductance $\left(\mathrm{g}_{\mathrm{a}}\right)$ during the daytime period in four phenological stages representative of the reproductive phase of irrigated cowpea (CV. BR3-Tracuateua), in the years 2013 (A and D), 2014 (B and E) and 2015 (C and F), under the climatic conditions of northeastern region of Pará state, Brazil 
the exchange of water vapor between plant and atmosphere due to the opening of the stomata. There are also stomatal closure and reduction of $g_{s}$ shortly after the period of maximum solar radiation.

Throughout the day, the increase in Tair and VPD intensified the movement of water vapor from the leaf to the atmosphere and, therefore, $g_{s}$ decreases in an attempt to reduce water loss by the plant. At dusk, despite the reduction of both Tair and VPD, the stomata tend to close in response to the reduction of solar radiation (Mott, 2009). Thus, $g_{s}$ tends to a minimum and constant value at the end of the daytime period.

The highest $g_{\mathrm{s}}$ values occur around solar noon, a fact also found in the study conducted by Oliveira et al. (2005) with the bean crop for the treatments that received partial replacement of crop evapotranspiration (ETc). It is possible to note the significant increase in stomatal conductance in the irrigated treatments (T100, T50 and T25) from $10 \mathrm{~h}$, because the plants are under favorable water conditions for the occurrence of evapotranspiration. In T0, there was a reduction in these values possibly due to an imbalance between the water vapor loss rate and the water supply, with a decrease in the stomatal pore and, consequently, in the transpiration rate.

The aerodynamic conductance showed variability similar to that observed for the wind speed throughout the day, indicating that the parameters are directly proportional and that, as wind speed increases, the exchange of water vapor between the crop and the atmosphere is favored. Thus, the evapotranspiration process is facilitated due to the increase in aerodynamic conductance (Souza Filho et al., 2005).

It is worth pointing out that $\mathrm{g}_{\mathrm{a}}$ varied also from one development stage to the other, increasing from the R5 stage to the R8 stage. As the cultivar has an indeterminate growth habit, plants continue to grow along the reproductive period and this contributes to the increase in plant height. Hence, the increase in height provides greater surface roughness, which gives it greater contact surface, facilitating the turbulent diffusion of water vapor (Monteith, 1965). However, at the R9 stage there was a decrease in $g_{a}$ due to the reduced plant stature.

In daily terms, the aerodynamic conductance tended to show high values in the first hours of the day, mainly due to the high values of wind speed in this period. This contributed to the reduction in boundary layer thickness and, despite the stomatal closure in the same period, the VPD facilitated the transfer of water vapor between the leaves and the atmosphere.

The variation of the decoupling factor for the three years of experiment is presented in Figure 4. Plants subjected to the T0 treatment indicate a tendency to coupling with the atmosphere, whereas irrigated plants (T100, T50 and T25) were decoupled during almost all developmental stages, possibly because of the water supply. However, the treatment T25 when exposed to a prolonged period of deficient irrigation showed a similar variation to that of the treatment $\mathrm{T} 0$.

The mean values of the decoupling factor, stomatal conductance and soil moisture are specified in Table 2. It can be observed that, in overall, the treatments under water stress
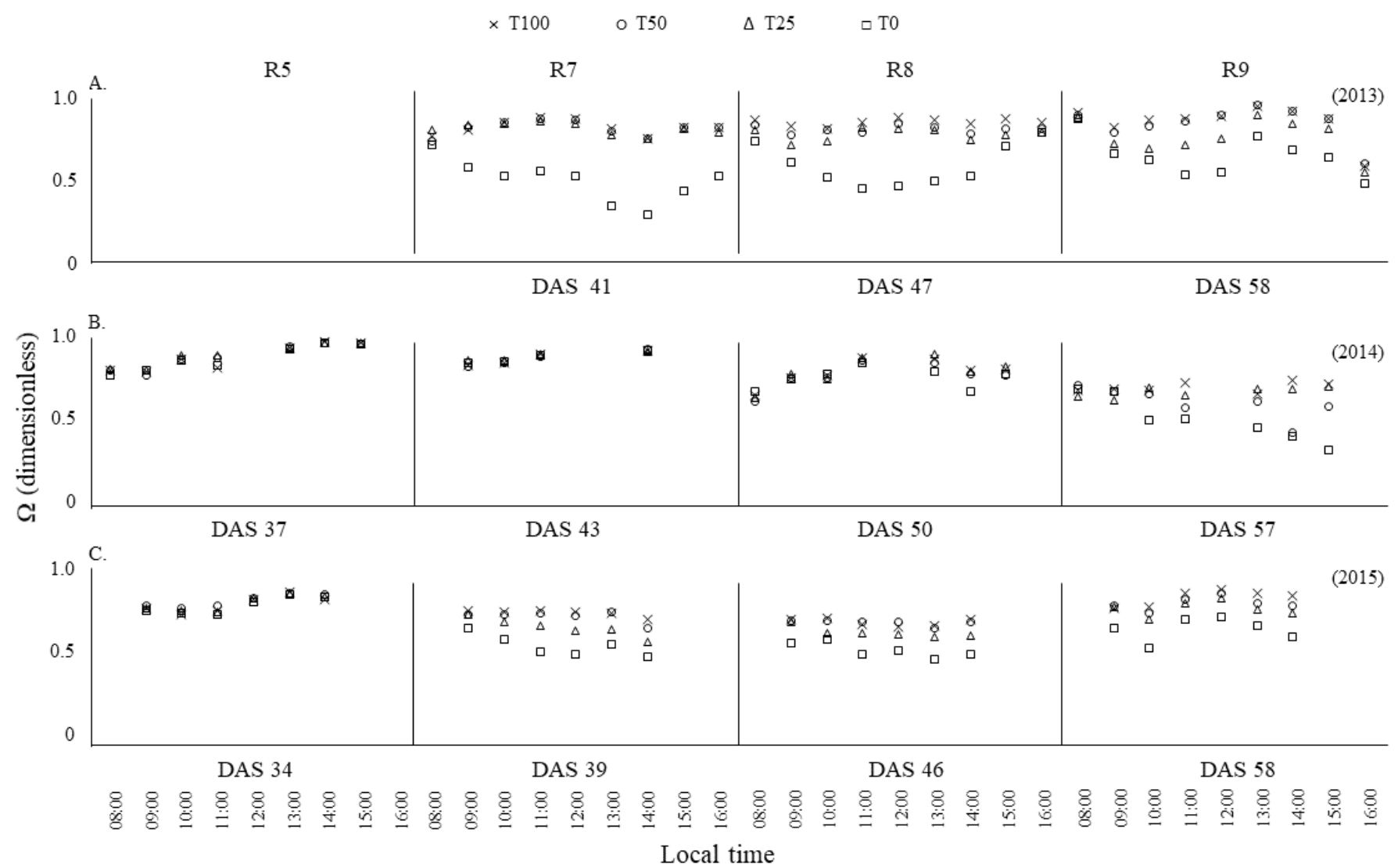

T100 - Replacement of $100 \%$ of the crop evapotranspiration (ETc); T50 - Replacement of 50\% ETc; T25 - Replacement of $25 \%$ ETc; and T0 - without replacement (without irrigation); R5 - First floral bud; R7 - First exposed pod; R8 - Grain filling; R9 - Physiological maturity; DAS - Days after sowing

Figure 4. Mean hourly variation of the decoupling factor $(\Omega)$ during the daytime period in four phenological stages representative of the reproductive phase of irrigated cowpea (cv. BR3-Tracuateua), in the years 2013, 2014 and 2015, under the climatic conditions of northeastern region of Pará, Brazil 
Table 2. Mean data of the decoupling factor $(\Omega)$, stomatal conductance $\left(g_{s}\right)$ and soil moisture content $(\theta \mathrm{s})$ for four phenological stages representative of the reproductive phase of irrigated cowpea (cv. BR3-Tracuateua), in the years 2013, 2014 and 2015, under the climatic conditions of northeastern region of Pará, Brazil

\begin{tabular}{|c|c|c|c|c|c|c|c|c|c|c|}
\hline & & \multicolumn{3}{|c|}{$\Omega$ (dimensionless) } & \multicolumn{3}{|c|}{$\mathrm{g}_{\mathrm{s}}\left(\mathrm{mmol} \mathrm{m} \mathrm{m}^{-2} \mathrm{~s}^{-1}\right)$} & \multicolumn{3}{|c|}{$\theta s\left(m^{3} m^{-3}\right)$} \\
\hline & & 2013 & 2014 & 2015 & 2013 & 2014 & 2015 & 2013 & 2014 & 2015 \\
\hline \multirow{4}{*}{ R5 } & T100 & & $0.89 \mathrm{aA}$ & $0.80 \mathrm{aA}$ & & $641.4 \mathrm{aA}$ & $366.4 \mathrm{aA}$ & & $0.18 \mathrm{bB}$ & $0.20 \mathrm{aA}$ \\
\hline & $\mathrm{T} 50$ & & $0.90 \mathrm{aA}$ & $0.83 \mathrm{aA}$ & & $639.2 \mathrm{aA}$ & $416.4 \mathrm{aA}$ & & $0.16 \mathrm{~dB}$ & $0.19 \mathrm{bA}$ \\
\hline & T25 & & $0.91 \mathrm{aA}$ & $0.81 \mathrm{aA}$ & & $721.6 \mathrm{aA}$ & 369.9 aA & & $0.18 \mathrm{aA}$ & $0.15 \mathrm{cB}$ \\
\hline & T0 & & $0.89 \mathrm{aA}$ & $0.80 \mathrm{aA}$ & & $560.6 \mathrm{aA}$ & $352.8 \mathrm{aA}$ & & $0.17 \mathrm{cA}$ & $0.14 \mathrm{~dB}$ \\
\hline \multirow{4}{*}{$\mathrm{R} 7$} & T100 & $0.80 \mathrm{aB}$ & $0.89 \mathrm{aA}$ & $0.75 \mathrm{cA}$ & $739.0 \mathrm{aA}$ & $648.4 \mathrm{aA}$ & $627.5 \mathrm{aA}$ & $0.19 \mathrm{aB}$ & $0.19 \mathrm{aB}$ & $0.21 \mathrm{aA}$ \\
\hline & $\mathrm{T} 50$ & $0.89 \mathrm{aB}$ & $0.89 \mathrm{aA}$ & $0.72 \mathrm{abC}$ & $714.4 \mathrm{a} A$ & $662.8 \mathrm{aA}$ & 316.6 bB & $0.18 \mathrm{bA}$ & $0.14 \mathrm{dC}$ & $0.17 \mathrm{bB}$ \\
\hline & T25 & $0.82 \mathrm{aB}$ & $0.90 \mathrm{aA}$ & $0.66 \mathrm{bC}$ & $680.0 \mathrm{aA}$ & 635.6 aA & $266.4 \mathrm{bcB}$ & $0.17 \mathrm{cB}$ & $0.17 \mathrm{bA}$ & $0.12 \mathrm{cC}$ \\
\hline & T0 & $0.50 \mathrm{bB}$ & $0.89 \mathrm{aA}$ & $0.57 \mathrm{cB}$ & $161.0 \mathrm{bB}$ & $620.8 \mathrm{aA}$ & $175.9 \mathrm{cB}$ & $0.16 \mathrm{dA}$ & $0.15 \mathrm{cB}$ & $0.11 \mathrm{dC}$ \\
\hline \multirow{4}{*}{ R8 } & T100 & $0.86 \mathrm{aA}$ & $0.81 \mathrm{aA}$ & $0.70 \mathrm{aB}$ & $743.5 \mathrm{aA}$ & $727.2 \mathrm{aA}$ & $352.3 \mathrm{aB}$ & $0.15 \mathrm{aC}$ & $0.17 \mathrm{aB}$ & $0.23 \mathrm{aA}$ \\
\hline & $\mathrm{T} 50$ & $0.82 \mathrm{abC}$ & $0.79 \mathrm{aA}$ & $0.70 \mathrm{aB}$ & $536.7 \mathrm{bA}$ & $624.7 \mathrm{aA}$ & $343.9 \mathrm{aB}$ & $0.14 \mathrm{aB}$ & $0.13 \mathrm{cC}$ & $0.17 \mathrm{bA}$ \\
\hline & T25 & 0.78 bA & $0.81 \mathrm{aA}$ & $0.64 \mathrm{aB}$ & $445.0 \mathrm{bB}$ & $755.8 \mathrm{aA}$ & $270.4 \mathrm{aC}$ & $0.06 \mathrm{bC}$ & $0.15 \mathrm{bA}$ & $0.10 \mathrm{cB}$ \\
\hline & T0 & $0.59 \mathrm{cB}$ & $0.78 \mathrm{aA}$ & $0.54 \mathrm{bB}$ & $193.1 \mathrm{cB}$ & $570.7 \mathrm{aA}$ & $175.0 \mathrm{aB}$ & $0.06 \mathrm{bC}$ & $0.15 \mathrm{bA}$ & $0.10 \mathrm{cB}$ \\
\hline \multirow{4}{*}{ R9 } & T100 & $0.86 \mathrm{aA}$ & $0.71 \mathrm{aA}$ & $0.83 \mathrm{aA}$ & $696.2 \mathrm{a} A$ & $520.1 \mathrm{aB}$ & $386.2 \mathrm{aC}$ & $0.23 \mathrm{aA}$ & $0.16 \mathrm{aC}$ & $0.21 \mathrm{aB}$ \\
\hline & T50 & $0.85 \mathrm{aA}$ & $0.61 \mathrm{aA}$ & $0.80 \mathrm{aA}$ & $640.4 \mathrm{aA}$ & 346.9 bB & $309.4 \mathrm{abB}$ & $0.21 \mathrm{bA}$ & $0.09 \mathrm{dC}$ & $0.12 b B$ \\
\hline & T25 & $0.77 \mathrm{aA}$ & $0.68 \mathrm{aA}$ & $0.77 \mathrm{aA}$ & $334.9 \mathrm{bB}$ & $445.7 \mathrm{abA}$ & 260.3 bB & $0.20 \mathrm{cA}$ & $0.11 \mathrm{cB}$ & $0.08 \mathrm{dC}$ \\
\hline & T0 & $0.65 \mathrm{aA}$ & $0.50 \mathrm{aA}$ & $0.65 \mathrm{aA}$ & $201.9 \mathrm{cA}$ & $235.3 \mathrm{cA}$ & $141.9 \mathrm{cA}$ & $0.19 \mathrm{dA}$ & $0.12 \mathrm{bB}$ & $0.09 c C$ \\
\hline
\end{tabular}

T100 - Replacement of 100\% of the crop evapotranspiration (ETc); T50 - Replacement of 50\% ETc; T25 - Replacement of $25 \%$ ETc; and T0 - without replacement (without irrigation); R5 - First floral bud; R7 - First exposed pod; R8 - Grain filling; R9 - Physiological maturity; Tukey test was applied at $\mathrm{p} \leq 0.05$; Lowercase letters refer to the comparison between treatments and uppercase letters refer to the comparison between years; Means followed by the same letter do not differ statistically

(T50, T25 and T0) had lower mean values of $\Omega, \mathrm{g}_{\mathrm{s}}$ and $\theta \mathrm{s}$, especially in the year 2015 .

The $\Omega$ factor showed no difference between treatments at the R5 and R9 stages. At R5, possibly because there was still an interference of the non-differentiation of the treatments in the vegetative phase, so much so that $g_{s}$ did not demonstrate statistical difference either. At this stage, the deficit treatments (T50, T25 and T0) subjected cowpea to very low accumulated water deficit, respectively $0.24,0.53$ and $0.92 \mathrm{~mm}$ in 2014 and $0.16,0.36$ and $0.64 \mathrm{~mm}$ in 2015. In R9, possibly because the physiological maturity stage occurred firstly in plants of the irrigated treatments (T100, T50 and T25).

For the factor $\Omega$, there was no statistical difference between the treatments in the year 2014 at the R7 and R8 stages and a significant difference was found from the R7 stage in 2013 and from R8 in 2015.

The means of $\theta$ s show that, when there is low water availability, evapotranspiration tends to be controlled by the plant. Thus, plants of the T100 treatment, under favorable conditions of water availability $\left(\theta s \approx 0.20 \mathrm{~m}^{3} \mathrm{~m}^{-3}\right)$, had full stomatal opening during the day, favoring gas exchanges, in such a way that the control of evapotranspiration is exclusively aerodynamic and dependent on energy availability.

The T25 treatment, despite receiving 25\% ETc replacement, indicated the variation of $\mathrm{g}_{\mathrm{s}}$ from 721.6 (R5) to $445.7 \mathrm{mmol} \mathrm{m}^{-2} \mathrm{~s}^{-1}$ (R9) in 2014 and from 369.9 (R5) to $260.3 \mathrm{mmol} \mathrm{m}^{-2} \mathrm{~s}^{-1}$ (R9) in 2015. These results are due to the reductions in $\theta$ s from 0.18 (R5) to $0.11 \mathrm{~m}^{3} \mathrm{~m}^{-3}$ (R9) in 2014 and from 0.15 (R5) to $0.08 \mathrm{~m}^{3} \mathrm{~m}^{-3}$ (R9) in 2015, causing a decrease in $\Omega$ values from 0.91 (R5) to 0.68 (R9) in 2014 and from 0.81 (R5) to 0.77 (R9) in 2015. Therefore, there is a tendency of coupling of the crop with the atmosphere; however, in 2013, for this same treatment (T25), $\mathrm{g}_{\mathrm{s}}$ decreased from 680.0 (R7) to $334.9 \mathrm{mmol} \mathrm{m}^{-2} \mathrm{~s}^{-1}$ (R9), and the factor $\Omega$ decreased from 0.82 (R7) to 0.77 (R9), despite the increase in $\theta$ s from 0.17 (R7) to $0.20 \mathrm{~m}^{3} \mathrm{~m}^{-3}$ (R9). Nonetheless, it should be pointed out that the increase in soil moisture was due to rain events between 48 and 59 DAS, totaling $123.6 \mathrm{~mm}$ of water entering the soil, which ended up temporarily eliminating the differences between treatments.

In 2013, until the period before the occurrence of rains, the deficient treatments (T50, T25 and T0) subjected cowpea to accumulated water deficits of 3.6, 7.5 and $12.7 \mathrm{~mm}$, respectively, which may have been the reason for the reductions observed both in the conductance and in the decoupling factor in the subsequent period. Results of studies on cowpea rehydration, after periods of water deficit, have shown that this crop recovers all physiological variables, even under moderate or severe stress (Nogueira et al., 2015).

It is observed that the plants reduce $\mathrm{g}_{\mathrm{s}}$ in order to minimize water losses and, therefore, the control of evapotranspiration becomes stomatal and according to the VPD. The same occurred for the non-irrigated treatment (T0), in which the plants reduced $g_{s}$ as a consequence of the mechanism of control of the stomatal opening and closing, in order to minimize the losses of water vapor by evapotranspiration.

The means of the $\Omega$ factor showed that, for treatments with water increment (T100, T50 and T25), there was greater control of evapotranspiration by the energy factor, while for the treatment $\mathrm{T} 0$ there is a tendency to stomatal control. However, it can be noted that, in the non-irrigated treatment, $\Omega$ values were close to or slightly higher than 0.5 . This result indicates that the crop is decoupled from the atmosphere, even to a lesser extent, when compared with the other treatments.

\section{Conclusions}

1. Stomatal conductance $\left(g_{s}\right)$ varied as a function of incident global solar radiation, air temperature, water vapor pressure deficit and soil moisture content. The aerodynamic conductance $\left(\mathrm{g}_{\mathrm{a}}\right)$ varied as a function of wind speed and plant stature.

2. Variation in the decoupling factor $(\Omega)$ along the day is due to the variation of stomatal conductance, which in turn is affected by solar radiation availability. 
3. The cowpea crop showed $\Omega$ values that indicated decoupling between the crop and the atmosphere in all treatments tested; however, such decoupling was less expressive for the treatment without irrigation.

\section{Literature Cited}

Allen, R. G.; Pereira, L. S.; Raes, D.; Smith, M. Crop Evapotranspiration: Guidelines for computing crop water requirements. Rome: FAO, 1998. 300p.

Alvares, C. A.; Stape, J. L.; Sentelhas, P. C.; Gonçalves, J. L. de M.; Sparovek, G. Köppen's climate classification map for Brazil. Meteorologische Zeitschrift, v.22, p.711-728, 2013. https://doi. org/10.1127/0941-2948/2013/0507

Bastos, E. A.; Ferreira, V. M.; Silva, C. R. da; Andrade Júnior, A. S. de. Evapotranspiração e coeficiente de cultivo do feijão-caupi no Vale do Gurguéia, Piauí. Revista Brasileira de Agricultura Irrigada, v.13, p.182-190, 2008. https://doi.org/10.15809/ irriga.2008v13n2p182-190

Brutsaert, W. Evaporation into the atmosphere. Dordrecht: Reidel, 1982. 299p. https://doi.org/10.1007/978-94-017-1497-6

Campos, M. S.; Alcantara, L. D. S. Interpretação dos efeitos de tempo nublado e chuvoso sobre a radiação solar em Belém/ PA para uso em sistemas fotovoltaicos. Revista Brasileira de Meteorologia, v.31, p.570-579, 2016. https://doi.org/10.1590/0102$7786312314 \mathrm{~b} 20150065$

Carvalho, H. de P.; Dourado Neto, D.; Teodoro, R. E. F.; Melo, B. de. Balanço hídrico climatológico, armazenamento efetivo da água no solo e transpiração na cultura de café. Bioscience Journal, v.27, p.221-229, 2011.

Coelho, C. A.; Cavalcanti, I. A. F.; Costa, S. M. S.; Freitas, S. R.; Ito, E. R.; Luz, G.; Santos, A. F.; Nobre, C. A.; Marengo, J. A.; Pezza, A. B. Climate diagnostics of three major drought events in the Amazon and illustrations of their seasonal precipitation predictions. Meteorological Applications, v.19, p.237-255, 2012. https://doi. org/10.1002/met.1324

EMBRAPA - Empresa Brasileira de Pesquisa Agropecuária. Sistema brasileiro de classificação de solos. 2.ed. Rio de Janeiro: Embrapa Solos, 2006. 306p.

Farias, V. D. da S.; Lima, M. J. A. de; Nunes, H. G. G. C.; Sousa, D. de P.; Souza, P. J. de O. P. de. Water demand, crop coefficient and uncoupling factor of cowpea in the eastern Amazon. Revista Caatinga, v.30, p.190-200, 2017. https://doi.org/10.1590/198321252017v30n121rc

Fernández, F. de C.; Gepts, P.; López, M. Etapas de desarrollo de la planta de frijol (Phaseolus vulgaris L.). Cali: Centro Internacional de Agricultura Tropical, 1986.33p.

Fraga, C. I. de M.; Sanches, L.; Pinto Junior, O. B.; Curado, L. F. A.; Gaio, D. C. Condutância do dossel, condutância aerodinâmica e fator de desacoplamento em floresta de Vochysia divergens Phol (Vochysiaceae) no pantanal brasileiro. Revista Brasileira de Meteorologia, v.30, p.275-284, 2015. https://doi.org/10.1590/0102778620130102

Freire Filho, F. R.; Cravo, M. da S.; Ribeiro, V. Q.; Rocha, M. de M.; Castelo, E. de O.; Brandão, E. dos S.; Belmino, C. S.; Melo, M. Í. S. de. BRS Milênio e BRS Urubuquara: Cultivares de feijão-caupi para a região Bragantina do Pará. Revista Ceres, v.56, p.749-752, 2009.
Grimm, A. M. El Niño, novamente! Revista Brasileira de Meteorologia, v.30, p.351-357, 2015. https://doi.org/10.1590/0102-778620152000

INMET - Instituto Nacional de Meteorologia. Normais climatológicas do Brasil 1961-1990. Brasília: INMET, 2009. 7p.

Lima, J. R. de S.; Antonino, A. C. D.; Lira, C. A. B. de O.; Souza, E. S. de; Silva, I. de F. da. Balanço de energia e evapotranspiração de feijão caupi sob condições de sequeiro. Revista Ciência Agronômica, v.42, p.65-74. 2011. https://doi.org/10.1590/S180666902011000100009

Lima, M. J.; Farias, V. D. S.; Costa, D. L. P.; Sampaio, L. S.; Souza, P. J. O. P. Efeito combinado das variáveis meteorológicas sobre a condutância estomática do feijão-caupi. Horticultura Brasileira, v.34, p.547-553, 2016. https://doi.org/10.1590/s0102053620160414

McNaughton, K. G.; Jarvis, P. G. Predicting effects of vegetation changes on transpiration and evaporation. In: Kozlowski, T. T. Water deficits and plant growth. New York: Academic Press, 1983. 47p. https://doi.org/10.1016/B978-0-12-424157-2.50007-0

Monteith, J. L. Evaporation and environment. In: Fogg, G. F. The state and movement of water in living organism. New York: Academic Press, 1965. Chap.19, p.205-234.

Mott, K. A. Opinion: Stomatal responses to light and $\mathrm{CO}_{2}$ depend on the mesophyll. Plant, Cell \& Environment, v.32, p.1479-1486, 2009. https://doi.org/10.1111/j.1365-3040.2009.02022.x

Nogueira, N. W.; Freitas, R. M. O. de; Dombroski, J. L. D.; Procópio, I. J. S.; Medeiros, R. de C. A.; Ribeiro Neto, J. A. Ecofisiologia de plantas de feijão-caupi sob efeito de estresse hídrico e reidratação nos sistemas de plantio direto e convencional. In: Congresso Brasileiro de Ciência do Solo, 35, 2015. Natal. Anais... Natal: SBCS, 2015. p.1-4.

Oliveira, A. D. de; Fernandes, E. J.; Rodrigues, T. de J. D. Condutância estomática como indicador de estresse hídrico em feijão. Engenharia Agrícola, v.25, p.86-95, 2005. https://doi.org/10.1590/ S0100-69162005000100010

Paulino Junior, N.; Randow, R. de C. S. von; Randow, C. von. Analysis of biological and meteorological controls of evapotranspiration in pristine forests and a pasture site in Amazonia. Revista Ambiente \& Água, v.12, p.179-191, 2017. https://doi.org/10.4136/ambiagua. 1832

Silva, T. G. F. da; Zolnier, S.; Moura, M. S. B. de; Carmo, J. F. A. do; Ribeiro, A. Fator de desacoplamento em um canavial irrigado no submédio do Vale do São Francisco. Revista Brasileira de Engenharia Agrícola e Ambiental, v.16, p.849-857, 2012. https:// doi.org/10.1590/S1415-43662012000800006

Souza, P. J. de O. P. de; Farias, V. D. de S.; Lima, M. J. A. de; Ramos, T. F.; Sousa, A. M. L. de. Cowpea leaf area, biomass production and productivity under different water regimes in Castanhal, Pará, Brazil. Revista Caatinga, v.30, p.748-759, 2017. https://doi. org/10.1590/1983-21252017v30n323rc

Souza, P. J. de O. P. de; Ribeiro, A.; Rocha, E. J. P. da; Botelho, M. D. N.; Sousa, A. M. L. de; Souza, E. B. de; Farias, J. R. B. Impacts of soyaben expansion on the Amazon energy balance: A case study. Experimental Agriculture, v.47, p.553-567, 2011. https://doi. org/10.1017/S0014479711000391

Souza Filho, J. D. da C.; Ribeiro, A.; Costa, M. H.; Cohen, J. C. P. Mecanismos de controle da variação sazonal da transpiração de uma floresta tropical no nordeste da Amazônia. Acta Amazônica, v.35, p.223-229, 2005. https://doi.org/10.1590/S004459672005000200012 